\title{
Analysis of the relationship between land use and the parasitism of sheep during their transhumance
}

\author{
Lucas GRUNER $^{\text {a*}}$, Christine SAUvéa ${ }^{\text {, Chantal BOULARD }}{ }^{\mathrm{a}}$, \\ Maurice CALAMEL ${ }^{\mathrm{b}}$ \\ a INRA, Bio-Agresseurs, Santé, Environnement, 37380 Nouzilly, France \\ ${ }^{\mathrm{b}}$ AFSSA, BP 111, 06902 Sophia-Antipolis, France \\ (Received 4 February 2005 - Accepted 31 January 2006)
}

\begin{abstract}
The aims were to identify the parasite communities and to relate the kinetics of infection to environmental factors during summer transhumance. A survey of parasitism of a sheep flock from the South-East of France was conducted during its summer transhumance in the Southern Alps. The flock was composed of 700 young Merino of Arles ewes. The 152 days of transhumance were spent grazing 3 pastures at an altitude of $1200 \mathrm{~m}, 4$ pastures at $1700 \mathrm{~m}$, and then spending 83 days between 2000 and $2500 \mathrm{~m}$ before returning back down to the same groups of lower pastures. The species of parasites present were identified in 5 tracer lambs collected 4 times during the survey. In addition, grass and faecal pellets on the pastures and on 28 alpine grasslands in the upper valley were sampled every month to look for the infective larvae of the gastrointestinal nematodes. Data for these grasslands and their use by the flock were available from the previous year. The main parasite species detected were the nematodes Teladorsagia circumcincta and Nematodirus spp.; the tracers collected about 4000 worms, mainly on the pre-alpine pastures. In the higher valley, considerable differences between the different areas were observed with regards to grass availability, pellet deposition and flock frequency. The pellets acted as a reservoir for over-wintering larvae. The most contaminated areas were those that had been grazed during August of the previous year. These findings were used to optimise flock management so as to limit infection and to prevent deterioration of the higher grasslands due to over-grazing and erosion.
\end{abstract}

sheep / transhumance / nematode parasite / epidemiology / mountain pasture / animal behaviour

Résumé - Analyse des relations entre l'utilisation de l'espace et le parasitisme des ovins au cours de leur transhumance. L'objectif était d'identifier la communauté de parasites et d'établir la cinétique de l'infestation en relation avec les caractéristiques environnementales au cours de la transhumance. Une étude a porté sur le parasitisme d'un troupeau ovin de la Plaine de Crau au cours de sa transhumance estivale dans les Alpes du sud. Le troupeau comprenait 700 agnelles Mérinos d'Arles. La transhumance de 152 jours s'est déroulée sur 3 prairies à $1200 \mathrm{~m}$ d'altitude, puis 4 prairies à $1700 \mathrm{~m}, 83$ jours d'alpage entre 2000 et $2500 \mathrm{~m}$ puis un retour sur les prairies de l'aller. La faune parasitaire était identifiée par l'autopsie de 5 agneaux traceurs prélevés à

\footnotetext{
* Corresponding author: Lgruner2801@aol.com

Present address: 30 rue du Haut Melotin, 37380 Reugny, France.
} 
4 occasions. Les populations de larves infestantes des nématodes gastrointestinaux étaient échantillonnées sur l'herbe et dans les fèces dans les prairies et dans 28 zones d'alpage de la vallée supérieure. Des données sur les caractéristiques de ces zones et sur leur fréquentation par le troupeau l'année précédente étaient disponibles. Le parasitisme était dominé par les nématodes Teladorsagia circumcincta et Nematodirus spp.; les traceurs ont collecté de l'ordre de 4000 vers, principalement sur les prairies sub-alpines. Dans la vallée supérieure, une grande hétérogénéité était observée dans la disponibilité en herbe, la quantité de fèces déposées et la fréquentation par le troupeau. Les fèces ont servi de réservoir des larves survivantes à l'hiver. Les zones les plus contaminées étaient celles utilisées en août de l'année précédente. Ces résultats permettent d'optimiser l'utilisation de ces vallées pour limiter l'infestation parasitaire mais aussi la dégradation des zones supérieures par le surpâturage et l'érosion.

ovin / transhumance / nématode parasite / épidémiologie / comportement animal

\section{INTRODUCTION}

Transhumance, or 'the seasonal moving of livestock to regions with a different climate', is a common husbandry practice in mountainous areas in several European countries. It is generally done to exploit the pastures available elsewhere when grass in the lowlands is in short-supply during the summer. The characteristics of parasitism have been clearly described in the synthesis by Eckert and Hertzberg [3]. The epidemiology of trichostrongylosis in cattle is characterised by the prolonged survival of infective larvae of Ostertagia ostertagi and Cooperia oncophora in cow pats under the snow. As a result, herds face the greatest risk of infection when they arrive in June. The level of contamination of the pastures then decreases, only to rise again by the end of the grazing season. This has been reported in Norway [7, 20], France [19], Sweden [15] and Austria [17]. In sheep, the course of infection is often affected by the fact that pre-alpine pastures are used before the alpine ones at higher altitudes. The dominant genera are Teladorsagia and $\mathrm{Ne}$ matodirus, as Trepp [21] observed in tracer lambs in Switzerland.

In the south of France, the large population of Merino of Arles sheep usually spends four to five months in transhumance during the dry summer of the Mediterranean climate to compensate for the lack of food available on their lowland pastures
[13]. Studies have been conducted to try to optimise the way these different grasslands are used by domestic herbivores [1].

In some parts of the Crau plain, pastures are regularly flooded and grass is produced all year round for grazing or hay production. Helminth parasites are particularly diversified and abundant in the flocks grazing these irrigated pastures compared to those on the surrounding naturally dry land, and the practice of transhumance is used to limit helminth infections [6]. The areas exploited during the transhumance have been investigated to describe the botanical composition of the slopes [9], their use by the sheep [10], and to assess whether some parts are under- or over-grazed in order to plan their optimum use [11]. Since these data were already available, the aim of this study was to describe the community of parasites collected during the transhumance, the levels of infection and to link this to the management of the grazing area, by regularly sampling a flock and the pastures and upper slopes it used.

\section{MATERIALS AND METHODS}

\subsection{The flock surveyed}

At the experimental farm of 'Le Merle' in the Crau plain of the Rhone delta (south of France), about two thousand Merino of 
Arles ewes were bred, and grazed on irrigated pastures and on dry land. The main mating period is in the spring. There is also a second one in the autumn for any ewes that are still dry after the spring mating. Every year, nearly all the sheep are moved to the high valley of the Var River (Southern Alps) from the end of May. The ewes due to lamb in early October return in late September, and the others come back during October. Our survey done in 1982 concerned a flock of 700 young ewes born in the autumn 1981, which were more likely to reveal the presence of parasites than older animals. Furthermore, their transhumance period was longer (5 months). Their average weight increased from $27.5 \pm 2 \mathrm{~kg}$ to $33 \pm 3 \mathrm{~kg}$.

The parasite communities present at 'Le Merle' farm were highly diversified [6], with gastrointestinal nematodes (not including the Haemonchus contortus species), protostrongylids, liver flukes (Fasciola hepatica and Dicrocoelium lanceolatum), Coenurus cerebralis, Monieza expansa, Cysticercus tenuicollis and the nasal bot fly Oestrus ovis. Regular treatments were administered during the spring and the autumn. Just before their departure, the ewes were treated with fenbendazole (at twice the recommended dose for sheep: $10 \mathrm{mg}$ per $\mathrm{kg}$ ) for gastrointestinal and protostrongylid nematode parasites, and with rafoxanide (dose of $7.5 \mathrm{mg}$ per $\mathrm{kg}$ ) for trematode parasites and Oestrus ovis.

\subsection{The transhumance}

The flock grazing schedule was as follows: three pastures in 'St Martin d'Entraunes' (1200 m above sea level) were used from May 27 to June 8, then 4 pastures in 'Esteing' (altitude $1700 \mathrm{~m}$ ) from June 9 to July 6, then the slopes of the 'Sanguinière' valley (altitude from 2000 to $2500 \mathrm{~m}$ ) from July 7 to September 28. The flock then came back down to the 'Este- ing' pastures (September 29 - October 14) and 'St Martin d'Entraunes' pastures (October 15-27). The meteorological data collected at an altitude of $1640 \mathrm{~m}$ gave an average annual rainfall of $1089 \mathrm{~mm}$ (51 and $75 \mathrm{~mm}$ in July and August respectively), and a monthly mean temperature of $-0.2{ }^{\circ} \mathrm{C}$ in January and $15.7^{\circ} \mathrm{C}$ in July. Snow was present from December to April at $1200-1500 \mathrm{~m}$, and from October to May above $2000 \mathrm{~m}$. The flock was managed by a shepherd with the help of a dog.

\subsection{Measurements and observations}

To estimate the level of infection in the flock, freshly deposited faeces from 20 ewes were collected in June, September and October for egg counts using the MacMaster method as modified by Raynaud [18], with magnesium sulphate as the floatation liquid $(\mathrm{d}=1.29)$. To identify the species collected during the season, 20 tracer Merino of Arles ewe lambs that had been born in February 1982 were added to the flock and treated again on June 6 to ensure that they were parasite free (this was confirmed by faecal analysis). Five of them were collected every month, transported to the AFSSA laboratory, where they were kept in pens for a month before necropsy. The liver, lungs, large intestine and head were examined during the necropsy to check for trematodes, lungworms, C. tenuicollis and Oestrus ovis, respectively. The abomasum, the small intestine and the caecum were frozen separately for further analysis at the INRA-Nouzilly laboratory. Gastrointestinal nematodes were extracted and counted by species and sex in aliquots of about $10 \%$ for the abomasum and small intestine, and in totality for the caecum.

Every month, blood samples were taken from the tracer lambs for further analysis of the antibody reaction towards $F$. hepatica using a specific antigen. Any snails and slugs observed in the different areas were 
collected, as possible intermediate hosts for the protostrongylids and D. lanceolatum. For F. hepatica, aquatic snails where looked for in the undisturbed slow-flowing edges of streams. The samples collected were kept alive at the INRA-Nouzilly laboratory in order to survey miracidium excretion, and to check for the presence of trematodes. After two months, any snails still alive were crushed between two slides to check further for the presence of parasites under a microscope.

The level of infection with trichostrongylid nematode larvae in the different pastures was estimated by sampling the grass and the faeces every month, as described by Gruner et al. [5] and Mounport et al. [14] for a heterogeneous terrain. Briefly, grass was sampled by picking 400 pinches (corresponding to about $3 \mathrm{~m}^{2}$ ) and any faeces present on the soil were sampled by collecting 200 samples located in a $20-\mathrm{cm}$ diameter ring $\left(6.2 \mathrm{~m}^{2}\right)$. The larvae were extracted in a Baermann apparatus, and their number was expressed as L3 per $\mathrm{kg}$ of dry faeces or dry grass or referred to the surface area of ground sampled.

The mountain pastures of the "Sanguinière" valley extend over hundreds of hectares, but ecological investigations had been conducted in this area in previous years. The botanical characteristics were mapped by Jouglet and Dubost [9], who described various different plant associations and their pastoral value for sheep. Taking the age and weight distribution in the flock into account, an estimation was made of the daily energy requirement of the flock. The pastoral value and the surface area of each homogenous feature gave its potential ability to support a given number of sheep during the grazing season. The slopes of the valley were divided into 56 areas on the basis of these combinations. During the previous grazing season, the way these features were used by the flock had been observed [10], and data were available for each of them on the dates of use, on the actual stocking rate (expressed in sheep per ha per year), and on the rate of use (ratio of observed/potential stocking rate). In order to pinpoint the risk of infection with gastrointestinal infective larvae in space and in time, we randomly selected 28 features out of the 56 to cover the range of altitude, orientation and botanical combinations. Every month we sampled grass and faeces from the same part of each area, in order to remove and count any infective larvae present. The grass and pellets collected were then dried and weighed. Some areas used by the flock as resting places at night or at midday were not included in the 28 sampled areas, because they had limited surface and the accumulation of faecal pellets was not representative of the grazing areas.

\subsection{Statistical analysis}

The relationships between the environment, its use by the sheep during the previous year and parasitism were investigated by identifying the risk of infection when the flock arrived in the 'Sanguinière' valley. The number of larvae in the grass (expressed in L3 per 400 pinches of grass) and faeces (expressed in L3 in the faeces collected and in L3 per $100 \mathrm{~g}$ of faeces) in the 28 features sampled at this time were compared with five available quantitative variables. Four had been measured during the previous grazing season. These were the stocking rate (SR) (in sheep per ha per year), the pastoral value (PV), the rate of use (RU), the interval since the last time the flock had used it and October 1 in the previous year (ILU, 1 to 4 weeks) (after this date, the temperature was too cold to allow the eggs deposited in the faeces to develop to L3). The fifth variable was the weight (in grams) of faeces (FW) remaining when the flock arrived, which expressed the intensity of grazing or resting. The number of 
Table I. Mean number (and range) of parasites found in the tracer lambs sampled every month during transhumance in the Alps.

\begin{tabular}{lcccc}
\hline Sampling date $(5$ tracers $)$ & 15 July & 13 August & 16 September & 14 October \\
Age of the tracers $(\mathrm{m})$ & 5 & 6 & 7 & 8 \\
Duration of grazing $(\mathrm{m})$ & 1.5 & 2.5 & 3.5 & 4.5 \\
\hline Oestrus ovis & 0 & $5 \mathrm{~L} 1(0-18)$ & 0 & 0 \\
Coenurus cerebralis & 0 & $0.2(0-1)$ & 0 & $0.6(0-1)$ \\
Cysticercus tenuicollis & 0 & 0 & 0 & 0 \\
Protostrongylids & $7(0-21)$ & $0.2(0-1)$ & $1(0-4)$ & $0.4(0-1)$ \\
Dicrocoelium lanceolatum & $42(32-50)$ & $77(9-277)$ & $28(2-70)$ & $23(0-75)$ \\
Fasciola hepatica & 0 & 0 & 0 & 0 \\
Teladorsagia circumcincta & 2468 & 2447 & 4161 & 3596 \\
& $(1-5773)$ & $(3-5750)$ & $(1116-7820)$ & $(1512-4920)$ \\
\% T. c. trifurcata & 14 & 10.1 & 14.1 & 11.2 \\
Haemonchus contortus & 9 & 5 & 0 & 0 \\
& $(0-45)$ & $(0-23)$ & & \\
Trichostrongylus vitrinus & 9 & 6 & 15 & 26 \\
& $(0-46)$ & $(0-20)$ & $(0-46)$ & $(0-80)$ \\
Nematodirus spp. & 1514 & 553 & 190 & 757 \\
\% N. spathiger & $(405-3792)$ & $(65-1180)$ & $(85-300)$ & $(80-2140)$ \\
$\%$ N. filicollis & 75.6 & 80.9 & 80 & 78 \\
\% N. abnormalis & 16.2 & 19.1 & 20 & 22 \\
\% N. chabaudi & 7.6 & 0 & 0 & 0 \\
Trichuris ovis & 0.5 & 0 & 0 & 0 \\
Total worms & $4(0-7)$ & $6(0-10)$ & $5(0-9)$ & $7(0-16)$ \\
& 4044 & 3089 & 4392 & 4788 \\
\hline & $(456-6903)$ & $(250-6996)$ & $(1430-7800)$ & $(1778-7639)$ \\
\hline & & & &
\end{tabular}

L3 and the weight of the faeces were logtransformed to stabilise the variance, and a square-root transformation was applied to the PV. The correlation matrix between these variables was calculated, and a stepwise correlation was performed to identify their main effect on the parasitic variables.

\section{RESULTS}

\subsection{Parasite communities in the tracer lambs and infection of the flock}

Only a few young larvae of $O$. ovis were observed in 3 lambs at mid transhu- mance (Tab. I). C. tenuicollis and F. hepatica were absent, and $C$. cerebralis and protostrongylids were rare. Moderate levels of D. lanceolatum were always present. The gastrointestinal nematode community was dominated by $T$. circumcincta, with about 2500 worms found at the two first sampling dates, when the level of infection in some individuals remained low. The burden then increased to 3600-4000 worms. Twelve percent of the $T$. circumcincta worms were the T.c. trifurcata morph. Nematodirus spp. were also abundant, mainly at the beginning and end of the grazing season, with about $80 \%$ of $N$. spathiger and $20 \%$ of 
Table II. Mean number (sd) of gastrointestinal infective larvae collected in the faeces and grass sampled on the various pastures and alpine grasslands during the summer transhumance in the Southern Alps.

\begin{tabular}{lccccc}
\hline Sampling date & 9 June & 15 July & 13 August & 16 September & 14 October \\
\hline 28 areas sampled in the 'Sanguinière' valley (altitude & $2000-2500 \mathrm{~m})^{1}$ & & \\
L3 per kg dry herbage & $98(144)$ & $63(155)$ & $23(60)$ & $30(26)$ & $8(20)$ \\
L3 per 100 g dry pellets & $965(2553)$ & $30(58)$ & $107(146)$ & $541(1784)$ & $733(1302)$ \\
$\%$ T. circumcincta* & 97 & 25.5 & 78 & 82 & 95.5 \\
$\%$ Nematodirus spp. & 2 & 74.5 & 18 & 16 & 4.5 \\
$\%$ Chabertia/Oesoph. & 1 & 0 & 4 & 2 & 0 \\
4 'Esteing' pastures (altitude $1700 \mathrm{~m})^{2}$ & & & & \\
L3 per kg dry herbage & $50(110)$ & $78(127)$ & $106(121)$ & $92(44)$ & $133(52)$ \\
L3 per 100 g dry pellets & $692(617)$ & $1(1)$ & $241(355)$ & $99(88)$ & $215(354)$ \\
$\%$ T. circumcincta & 3 & 59 & 50 & 55 & 84 \\
$\%$ Nematodirus spp. & 97 & 41 & 50 & 45 & 16 \\
$\%$ Chabertia/Oesoph. & 0 & 0 & 0 & 0 & 0 \\
3 'St Martin d'Entraunes' pastures (altitude $1200 \mathrm{~m})^{3}$ & & & \\
L3 per kg dry herbage & $34(16)$ & $329(352)$ & $141(150)$ & $191(253)$ & $129(141)$ \\
L3 per 100 g dry pellets & $32(55)$ & $18(5)$ & $21(20)$ & $4(6)$ & $0(0)$ \\
$\%$ T. circumcincta & 74 & 62 & 70 & 51 & 35 \\
$\%$ Nematodirus spp. & 26 & 37 & 21 & 49 & 65 \\
$\%$ Chabertia/Oesoph. & 0 & 1 & 9 & 0 & 0 \\
\hline
\end{tabular}

* Including some L3 of Trichostrongylus sp.; Oesoph.= Oesophagostomum.

${ }^{1}$ Presence of the flock from 7 July to 28 September.

${ }^{2}$ Presence of the flock from 9 June to 6 July and from 29 September to 14 October.

${ }^{3}$ Presence of the flock from 27 May to 8 June and from 15 to 27 October.

N. filicollis. N. abnormalis and N. chabaudi were only observed at the beginning of the grazing season. Some $H$. contortus, $T$. vitrinus and $T$. ovis were also found.

The level of infection of the flock, measured as the number of eggs per gram (epg) of fresh faeces deposited by 20 ewes was 16 epg in June, 205 in September and 250 in October. No values were available for July or August.

\subsection{Contamination of the pastures and alpine grasslands (Tabs. II and III)}

At the higher altitudes, we found only one slug at the altitude of $2200 \mathrm{~m}$, and two small populations of the aquatic snail Limnaea peregra at $2000 \mathrm{~m}$. They did not excrete any miracidia when kept in the laboratory, and so were concluded not to have been parasitised.

The three pastures used at the lowest altitude for 13 days were mainly infected with T. circumcincta and Nematodirus spp. At $1700 \mathrm{~m}$, the four pastures used for 27 days were mainly infected with Nematodirus spp. The faecal pellets constituted the main reservoir of over-wintering infective larvae in early spring. In July, these larvae leave the pellets and migrate onto the grass. The new generation of larvae 
Table III. Number of infective larvae (in L3 per $\mathrm{m}^{2}$ ) collected in 400 pinches of grass (equivalent to $3 \mathrm{~m}^{2}$ ) and in faecal pellets (collected over $6 \mathrm{~m}^{2}$ ) and mean weight of grass and pellets (in dry matter per $\mathrm{m}^{2}$ ) collected in each area sampled (and range).

\begin{tabular}{|c|c|c|c|c|c|}
\hline Sampling date & 9 June & 15 July & 13 August & 16 September & 14 October \\
\hline \multicolumn{6}{|c|}{28 areas sampled in the 'Sanguinière' valley (altitude $2000-2500 \mathrm{~m}$ ) } \\
\hline $\mathrm{L} 3$ in grass per $\mathrm{m}^{2}$ & $1.1(0-7)$ & $1.0(0-11)$ & $0.4(0-6)$ & $0.7(0-6)$ & $0.6(0-4)$ \\
\hline g dry grass per $\mathrm{m}^{2}$ & $10(5-13)$ & $19(10-34)$ & $22(4-53)$ & $19(4-25)$ & $10(4-22)$ \\
\hline $\mathrm{L} 3$ in pellets per $\mathrm{m}^{2}$ & $77(0-695)$ & $3(0-25)$ & $15(0-44)$ & $50(0-310)$ & $193(0-294)$ \\
\hline $\mathrm{g}$ dry pellets per $\mathrm{m}^{2}$ & $13(0-32)$ & $9(0-23)$ & $13(0-24)$ & $22(0-92)$ & $9(5-21)$ \\
\hline \multicolumn{6}{|c|}{4 'Esteing' pastures (altitude $1700 \mathrm{~m}$ ) } \\
\hline $\mathrm{L} 3$ in grass per $\mathrm{m}^{2}$ & $1.2(1-2)$ & $2.7(0-10)$ & $2.0(0-5)$ & $2.3(2-3)$ & $4.2(1-6)$ \\
\hline g dry grass per $\mathrm{m}^{2}$ & $24(15-35)$ & $31(13-40)$ & $24(17-37)$ & $30(19-52)$ & $31(9-57)$ \\
\hline $\mathrm{L} 3$ in pellets per $\mathrm{m}^{2}$ & $24(1-34)$ & $0.1(0-0.5)$ & $8.2(2-14)$ & $10(0-33)$ & $15(0-42)$ \\
\hline $\mathrm{g}$ dry pellets per $\mathrm{m}^{2}$ & $5(1-12)$ & $12(8-14)$ & $7(2-11)$ & $6(0-16)$ & $14(6-26)$ \\
\hline \multicolumn{6}{|c|}{3 'St Martin d’Entraunes' pastures (altitude 1200 m) } \\
\hline $\mathrm{L} 3$ in grass per $\mathrm{m}^{2}$ & $0.8(0-1)$ & $6.7(2-14)$ & $2.7(1-5)$ & $4(1-9)$ & $2.2(0-5)$ \\
\hline $\mathrm{g}$ dry grass per $\mathrm{m}^{2}$ & $23(16-29)$ & $26(19-38)$ & $25(16-34)$ & $23(19-30)$ & $20(7-36)$ \\
\hline $\mathrm{L} 3$ in pellets per $\mathrm{m}^{2}$ & $1.9(0-6)$ & $1.5(1-4)$ & $0.4(0-1)$ & $0.4(0-1)$ & $0.3(0-1)$ \\
\hline $\mathrm{g}$ dry pellets per $\mathrm{m}^{2}$ & $4(0-12)$ & $10(3-16)$ & $2(0-6)$ & $4(0-12)$ & $2(0-4)$ \\
\hline
\end{tabular}

emerging from the eggs deposited by the flock appeared in August.

There was less grass on the slopes of the 'Sanguinière' valley than in the pastures used at lower altitudes (Tab. III). The availability of grass increased during the summer, and decreased at the end of the grazing season (when the amount of grass being consumed by the sheep outstripped its rate of growth). The infective larvae were located mainly in the pellets, and the new generation increased in SeptemberOctober. The density of larvae in the grass remained at a moderate level, but there were considerable disparities between the 28 areas sampled.

\subsection{Relationships between contamination and the use of the areas by the sheep}

At the beginning and end of the 83 days when the flock was present in the 'San- guinière' valley, the sheep spent the night in a shelter located in the lower part of the valley. Every day, the shepherd set out in a different direction, and the flock grazed and made their way up to the higher grasslands. During the middle part of this period, the flock spent the night in one of several resting places located in the upper part of the valley; the shepherd rejoined the flock the next morning, and led the animals down to lower grasslands. A wide range of larval densities and amounts of faeces were found in the different areas sampled. This management pattern was similar to what had happened during the previous grazing season, for which observations and quantitative data were available for the same areas [10]. The pastoral value ranged from 10.7 to 25.2 , the observed stocking rate from 0.13 to 1.34 sheep per ha per year, and the rate of use from 0.09 to 1.91 . The interval between October 1 and the last time the flock had used the area ranged from 1 to 4 weeks. 


Coefficient of regression r
Weight of sampled faeces
Total L3 in sampled faeces
L3/100 g of dry faeces
Interval last use - October 1
Stocking Rate
Use Rate
Pastoral Value
L3 on sampled grass

Figure 1. Dendrogram between the variables measured during the transhumance in the 'Sanguinière' valley and the distribution of the infective larvae of gastrointestinal nematodes measured on 28 areas at the end of the winter.

The matrix of correlation was used to plot a dendrogram (Fig. 1). Two groups of variables were defined: the total number of L 3 in the pellets sampled in the area was closely correlated to the density (expressed in L3 per $100 \mathrm{~g}$ of dry faeces), and positively related to the interval (in weeks) since the last time the area had been used by the flock. It was moderately closely correlated to the amount of faeces. The second group of variables significantly linked the stocking rate and the usage rate, which was correlated to the pastoral value of the grass, and then to the density of L3 on the grass. These two groups were positively correlated.

By using a stepwise analysis (Tab. IV), the number of L3 in the grass was shown to be primarily correlated to the stocking rate; $45 \%$ of the variability in the number of L3 in the faeces could be explained by four variables, the interval since it was last used and October 1, the weight of faeces, the pastoral value and the stocking rate.

\section{DISCUSSION}

\subsection{Community of parasites}

The scarcity of ground molluscs explained the absence of Protostrongylids, but our observations were incomplete, since $D$. lanceolatum was in fact still present. This species is very common in sheep flocks in pre-alpine hills in the Mediterranean climate of southeast France [2]. The aquatic snail species of $L$. peregra' collected at $2000 \mathrm{~m}$, is not an intermediate host for $F$. hepatica, which was not found in the tracer lambs. The ELISA test using a specific antigen carried out on all the blood samples collected every month from the tracers was never positive (data not shown), confirming the absence of any contact with $F$. hepatica. The community of nematodes was dominated by $\mathrm{T}$. circumcincta and $\mathrm{Ne}$ matodirus spp. (mainly N. spathiger and $N$. filicollis). Only some individuals of H. contortus, T. vitrinus and Chabertia/Oesophagostomum were collected. This latter species was only observed in the form of infective larvae on the pastures, and no adult worm was found in the tracers. The two dominant species are commonly reported in mountain locations [3, 21].

Our study involved an environment with a Mediterranean climate, i.e. quite hot and dry during the summer, and so the supply of grass was quite poor. Since the 'Sanguinière' valley was nearly closed off and surrounded by rocky cliffs, other wild 
Table IV. Ranking of the main factors accounting for the distribution of the infective larvae of gastrointestinal nematode parasites at the end of the winter on the 28 areas of the "Sanguinière" valley grazed during the preceding transhumance season (multiple regression coefficients from a stepwise analysis).

\begin{tabular}{lcccc}
\hline Explained & \multicolumn{4}{c}{ Explaining variables } \\
Variable & first & second & third & fourth \\
\hline L3 per 400 pinches of grass & SR $\left(0.389^{*}\right)$ & ILU $\left(0.424^{*}\right)$ & UR $\left(0.441^{*}\right)$ & PV $(0.477 *)$ \\
Total L3 in sampled faeces & ILU $\left(0.523^{* *}\right)$ & FW $\left(0.595^{* *}\right)$ & PV $\left(0.648^{* *}\right)$ & SR $(0.672 * *)$ \\
L3 per 100 g dry pellets & ILU $\left(0.493^{* *}\right)$ & PV $\left(0.547^{* *}\right)$ & SR $(0.577 *)$ & UR $(0.609 *)$ \\
\hline
\end{tabular}

$\mathrm{SR}=$ stocking rate, ILU = interval between October 1 and last use; FW = faeces weight; PV = pastoral value; $\mathrm{UR}=$ use rate.

Value of r significant at $P<0.05$ (*) or $P<0.01$ (**).

mammals, such as the chamois (Rupicapra rupicapra) were absent; the marmot (Arctomys marmota) was present. This could explain the paucity of exchanges of parasite species between wild and domestic herbivores that other studies have demonstrated in Alpine situations $[8,16]$ in France, [4, 21] and in Italy [22]. These exchanges mainly involved Protostrongylids, but also a number of Trichostrongylid species that were not found in this survey.

\subsection{Kinetics of infection}

The first group of tracer lambs was collected after the pastures located at altitudes of 1200 and $1700 \mathrm{~m}$ had been used. The worm burden was about 4000 worms by summing the two main species. These pastures were highly productive, and the faeces quickly disappeared from the soil surface. The new eggs deposited by the flock developed to the L3 stage within a few weeks, and a quite high level of contamination persisted when the flock returned in late September and October. The L3 population of the 4 'Esteing' pastures played a major role in infecting the flock. During the 83 days spent on the higher grasslands, T. circumcincta was the main species ingested by the flock. The L3 population of this species was dominant on the grass in July, and then the new generation of larvae was observed in the pellets in August and September (Tab. II). The tracers sampled in August and September had accumulated more of this species, and their burden had increased. As they were getting older, their acquired immunological resistance limited this increase, and the burdens reported in September and October probably did not represent the number of larvae ingested. Since a similar phenomenon occurred in the ewes of the flock, the observed burden is still a useful parameter and reflects what is actually happening in the flock.

The slopes of the 'Sanguinière' valley were varied in terms of their botanical composition and the amount of grass available (Tab. III). On average, there was less grass than in the pastures, but some of the areas sampled actually had more grass in August (53 g dry grass per $\mathrm{m}^{2}$ ). This indicated that some areas were being poorly grazed. The low rate of use confirmed this. A large amount of grass under the forest in lower areas was undergrazed and lost. Inversely, a rate of use of more than 1 (1.91 was the maximum observed value) indicated that some areas were being overgrazed. Lambertin [10] also observed that the natural tendency of the sheep to climb and graze the upper areas very early led 
to a decrease in the grass cover and the erosion of the soil surface as a result of rainfall. The amount of pellets on the soil surface reflected the intensity of the presence of the flock, as Gruner et al. [5] and Mounport et al. [14] demonstrated on varied lands freely grazed by sheep. The rapid disappearance of the faeces meant that the L3 populations were not simultaneously present in the faeces and on the grass; there was no close correlation between the number of L3 in pellets and in the grass $(r=0.35)$. The interval between October 1 and the last time the flock had been present during the previous year was an important factor (Tab. IV). Half of the sampled areas on the 'Sanguinière' slopes were grazed both at the beginning and at the end of the transhumance, giving values of one or two weeks for the interval between October 1 and last time of use; the other half were grazed mid season, giving values of four weeks. This was a very significant predictive factor for a high level of over-wintering L3 in the faeces, and a positive relationship was found: early spring L3 were mainly found in areas that had been used for 4 weeks before October 1 , which were the areas used in August. This new finding could be useful in optimising the use of the 'Sanguinière' valley; when the flock first arrives, the shepherd could try to lead it to areas that had not been used in August during the previous transhumance season. In another location on the 'Causse' plateau (1000 m above Mediterranean sea level), Gruner et al. [5] have identified areas with certain botanical characteristics as having higher infection risk (areas with higher contamination), since the flock was without a shepherd on varied land. In the Mediterranean garrigue, sheep grazing freely from spring to autumn selected some grasslands characterised by specific botanical combinations and the ability of the plants to survive in a drought situation [14]. These areas were more often visited, and faeces containing nematode eggs were deposited. The pellets constituted a reservoir of L3, which were released with the first rainfall after the summer drought. In the Alps, storms were common, so L3 in pellets were released on many occasions, and so even if they were not present in very high levels, the sheep ingested larvae located on the little grass available. Lambertin et al. [11] and Molenat et al. [12] estimated the potentialities of these alpine grasslands after taking into account the phenology of the plant species, and the best periods for their utilization by the sheep were deduced. They proposed that areas with Nardus stricta should be used first, and then the areas under the forest for a few days in order to maintain sufficient resources for the second visit at the end of the season. These areas had been under-grazed during previous years. After this, the upper areas should be grazed by sectors, taking care to limit the use of the crests and any areas liable to erosion. The season would then end by using the areas under forest and containing N. stricta for the second time. Combining their proposals with our recommendations should help to limit the infection of the flock by gastrointestinal nematodes. This should be possible by avoiding using the areas that had been grazed in August the previous year too early. Since the L3 populations fall quickly from June to July and August, if they are not grazed until August, the rate of infection should remain moderate.

\section{CONCLUSION}

During transhumance in the Southern Alps, we found that sheep were mainly infected with gastrointestinal nematode parasites, predominantly $T$. circumcincta and Nematodirus spp. Infection occurred first in the pre-alpine pastures. Over-wintering infective larvae remaining in the faecal pellets were the source of this infection. In 
the upper valleys, the most contaminated alpine grasslands were those that had been grazed during the month of August the previous year. These findings make it possible to optimise the management of the use of these valleys to prevent the sheep from being infected early on, and to limit soil erosion due to overgrazing. This study is of interest for the verification of other situations having cold winter conditions and being used during transhumance.

\section{ACKNOWLEDGEMENTS}

We are grateful to the staff of the 'Le Merle' experimental farm who managed the flock before, during and after the transhumance.

\section{REFERENCES}

[1] Bailey D.W., Dumont B., Wallis De Vries M., Utilization of heterogeneous grasslands by domestic herbivores: theory to management, Ann. Zootech. 47 (1998) 321-333.

[2] Calamel M., La dicrocoeliose ovine et caprine dans le sud-est de la France, Rev. Méd. Vét. 127 (1976) 1529-1536.

[3] Eckert J., Hertzberg H., Parasite control in transhumant situations, Vet. Parasitol. 54 (1994) 103-125.

[4] Genchi C., Manfredi M.T., Bossi A., Les infestations naturelles par les strongles digestifs sur les pâturages de haute montagne : interaction entre la chèvre et le chamois, in: Les maladies de la chèvre, Niort, France, INRA Ed., 9-11 octobre, 1984, pp. 501-505.

[5] Gruner L., Bouley N., Hubert D., Mauléon H., Sauvé C., Caractérisation de zones à risque parasitaire pour les ovins élevés en liberté sur le parcours des Causses. 1. Méthodologie d'études et application aux strongles gastrointestinaux, Ann. Rech. Vét. 14 (1983) 287-300.

[6] Gruner L., Cabaret J., Utilisation des parcours méditerranéens et parasitisme interne des ovins, in: Exploitation des milieux difficiles par les ovins et les caprins, $10^{\mathrm{e}}$ Journées de la Recherche Ovine et Caprine,
INRA-ITOVIC, ITOVIC-SPEOC Ed., 1985, pp. 307-335.

[7] Helle O., The significance of winter survival of free-living stages on the epidemiology of nematodiasis: its effect in connection with set-stocking and alternate grazing with sheep and cattle, in: Nansen P., Jorgensen R.J., Soulsby E.J.L. (Eds.), Epidemiology and Control of Nematodiasis in Cattle, Martinus Nijoff, The Hague, 1981, pp. 287-286.

[8] Hugonnet L., Montagut G., Euzeby J., Incidences réciproques des infestations helminthiques des ruminants sauvages et des ovins domestiques en alpage de la Vanoise, Bull. Soc. Vét. Méd. Comparée 83 (1981) 193-199.

[9] Jouglet J.P., Dubost M., Inventaire phytosociologique de l'alpage de Sanguinière (Alpes Maritimes), CEMAGREF-INERM Ed., Grenoble, France, 1981, 12 p.

[10] Lambertin M., Le Mérinos d'Arles dans la montagne de Sanguinière. Étude écoéthologique, DES, Univ. Sci. Techn. Languedoc, Montpellier, France, 1982, 50 p.

[11] Lambertin M., Lapeyronie P., Molenat G., De l'écofaciès au plan de pâturage, une gestion raisonnée des alpages basée sur l'évolution de la valeur des végétations, Renc. Rech. Ruminants 2 (1995) 69-72.

[12] Molénat G., Dureau R., Fabre P., Lambertin M., Les herbes des troupeaux ovins transhumants de Crau. Multiples dimensions d'une gestion pastorale et fourragère, Fourrages 176 (2003) 437-461.

[13] Molénat G., Prud'hon M., Recurt Y., Les races transhumantes, caractéristiques et aptitudes, in: L'homme et le mouton dans l'espace de transhumance, Ed. Glénat, Grenoble, France, 1994, pp. 213-220.

[14] Mounport D., Gruner L., Lagacherie M., Utilisation des garrigues par les ovins et risque parasitaire vis à vis des strongles gastro-intestinaux, Ecologia Mediterranea 15 (1989) 145-159.

[15] Nilsson O., Winter ostertagiosis in Swedish cattle, in: Nansen P., Jorgensen R.J., Soulsby E.J.L. (Eds.), Epidemiology and Control of Nematodiasis in Cattle, Martinus Nijoff, The Hague, 1981, pp. 295-300.

[16] Nocture M., Cabaret J., Hugonnet-Chapelle L., Protostrongylid nematode infection of chamois (Rupicapra rupicapra) at the 
Bauges massif (French Alps), Vet. Parasitol. 77 (1998) 153-161.

[17] Prosl H., Zur Epidemiologie der Trichostrongylidose der Rinder auf öterreichischen Almweiden, Wien. Tierärztl. Monat. 73 (1986) 338-358, 379-392, 422-440.

[18] Raynaud J.P., Étude de l'efficacité d'une technique de coproscopie quantitative pour le diagnostic de routine et le contrôle des infestations parasitaires des bovins, ovins, équins et porcins, Ann. Parasitol. Hum. Comp. 45 (1970) 321-342.

[19] Raynaud J.P., Gruner L., Feasibility of herbage sampling in large extensive pasture and availability of cattle nematode infective larvae in mountain pastures, Vet. Parasitol. 10 (1982) 57-64.

[20] Tharaldsen J., Helle O., Epidemiological investigations of trichostrongylid infections in young cattle in different parts of Norway, Acta Vet. Scand. 29 (1984) 164-186.

[21] Trepp H.C., Epizootologische Untersuchungen über den Magen-Darm-Strongyliden-Befall des Schafes, Vet. Diss., Universität Zürich, 1973.

[22] Zaffaroni E., Manfredi M.T., Citterio C., Sala M., Piccolo G., Lanfranchi P., Host specificity of abomasal nematodes in free ranging alpine ruminants, Vet. Parasitol. 90 (2000) 221-230. 